\title{
Enzymatic Reduction of Levoglucosenone by an Alkene Reductase (OYE 2.6): a Sustainable Metal- and Dihydrogen-free Access to the Green Solvent Cyrene ${ }^{\circledR}$
}

\author{
Louis M. M. Mouterde ${ }^{a}$, Florent Allais ${ }^{a} *$, Jon D. Stewart ${ }^{\text {b* }}$
}

Levoglucosenone (LGO) has been successfully converted into the green polar aprotic solvent $\mathbf{2} \mathbf{H}$-LGO (aka Cyrene ${ }^{\circledR}$ ) through an enzymatic process involving alkene reductases: wild-type Old Yellow Enzyme 2.6 (OYE 2.6 wt.) from Pichia stipidis and its mutant that present the best conversion rates (OYE 2.6 $\left.\mathrm{Tyr}^{78} \mathrm{Trp}\right)$. This enzymatic process has been optimized in order to avoid the formation of the side-product (1S,2R)-2-hydroxy-6,8dioxabicyclo[3.2.1] octan-4-one (OH-LGO) and reach total conversion (99\%). Cyrene ${ }^{\circledR}$ was then succesfully isolated by continuous extraction in quantitative yields (99\%).

\section{Introduction}

2H-LGO $\left(\right.$ Cyrene $\left.{ }^{\circledR}\right)$ is a highly valuable renewable chemical that can be obtained from the reduction of the alkene moiety of Levoglucosenone (LGO), a relatively complex chiral chemical platform derived from the catalytic aerobic pyrolysis (CFP), such as Furace $I^{\mathrm{TM}}$ process, of cellulose and hemicellulose (Scheme 1). ${ }^{1,2}$

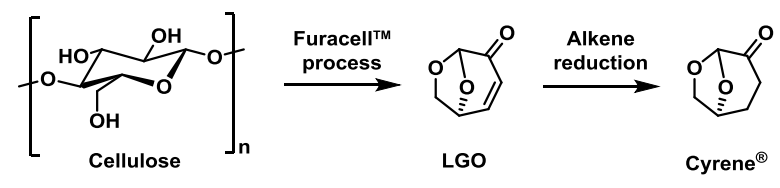

Scheme 1. Synthetic route to cellulose-based Cyrene ${ }^{\circledR}$

Cyrene ${ }^{\circledR}$ has been recognized as a safe and promising substituent for toxic dipolar aprotic solvent, such as NMP, DMF or sulpholane, ${ }^{3}$ and many examples of its successful utilization in a wide variety of organic reactions, ${ }^{4}$ such as amide coupling, ${ }^{5}$ Suzuki-Miyaura cross-coupling, ${ }^{6}$ synthesis of ureas, ${ }^{7}$ dispersion of graphene, ${ }^{8}$ Sonogashira cross-coupling and Cacchi-type annulation $^{9}$ and metal-org frameworks (MOF) synthesis, ${ }^{10}$ have been described in the literature (Scheme 2). Furthermore, Cyrene ${ }^{\circledR}$ can be used as building block for the synthesis of compounds of interest, such as $\mathbf{2 H}$-LGO-based oximes ${ }^{11}$ or $(\mathrm{S})-\gamma$ hydroxymethyl- $\alpha, \beta$-butyrolactone, ${ }^{12,13}$ a known precursor of dairy lactone.All the methods described in the literature to access Cyrene $^{\circledR}$ involve a metal catalyst and dihydrogen. ${ }^{13-24}$ Despite being efficient in terms of yields and cost, not only these methods can be dangerous to perform - notably at large scale - (i.e., dihydrogen), but the presence of potential metal residues - even in ppm quantities - in Cyrene ${ }^{\circledR}$ may also limit its utilization in certain applications. ${ }^{25-27}$ These drawbacks could thus limit the potential of Cyrene ${ }^{\circledR}$, specifically in the food/feed, cosmetic and pharmaceutical sectors.

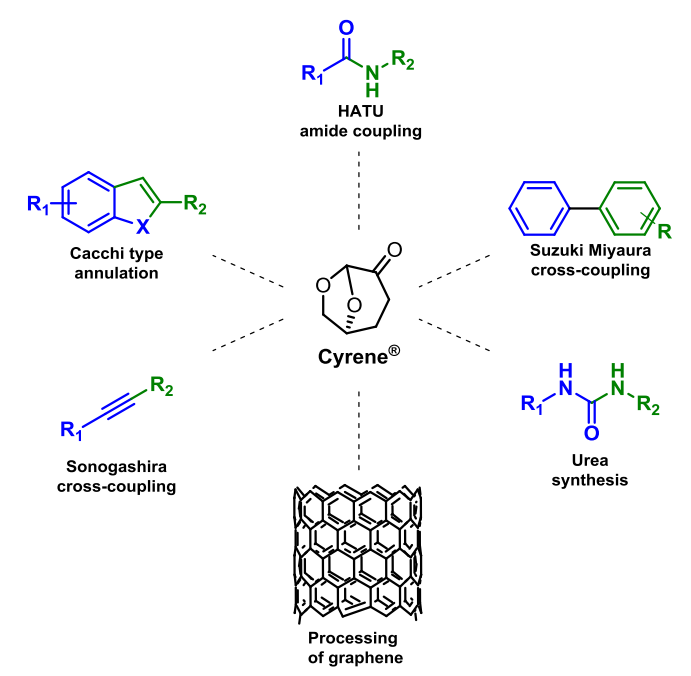

Scheme 2. The different applications of $\mathrm{Cyrene}^{\circledR}$ as green solvent

In order to offer a greener method to access $\mathrm{Cyrene}^{\circledR}$, the use of an alkene reductase, the Old Yellow Enzyme 2.6 (OYE 2.6) from Acinetobacter sp., seemed to be a good alternative to the classical methods. Indeed, OYEs are Flavin-dependent enzymes that catalyze the reduction of $\alpha, \beta$-unsaturated ketones. The substrate diversity of this enzyme is relatively wide, accepting 
compounds such as carvone, pulegone, 2-methyl-2-cyclopentenone, 3-methylfuran-2(5H)-one and other analogs with more or less bulky groups. ${ }^{28}$ The proven flexibility of OYE 2.6 allowed us to prognosticate a good activity in regard to LGO.

\section{Results and Discussion}

The first step of this study dealt with the determination of the activity of OYE 2.6 toward LGO. All OYEs appear to follow a ping-pong mechanism where the first step is the reduction of the tightly bound Flavin Mononucleotide (FMN) cofactor by Nicotinamide Adenine Dinucleotide Phosphate (NADPH). The resulting NADP ${ }^{+}$leaves the active site, allowing access for the substrate to enter. In the case of OYE 2.6, the $\alpha, \beta$-unsaturated ketone, stabilized by two histidine residues, undergoes reduction to the corresponding saturated product which in turn dissociates to concede its place to another NADPH molecule in order for the catalytic cycle to continue. ${ }^{29}$ The enzymatic reaction was first tested with OYE $2.6 \mathrm{Tyr}^{78} \mathrm{Trp}$, the most known active mutant of this enzyme. ${ }^{28}$ The original procedure consisted in the addition of OYE $2.6 \operatorname{Tyr}^{78} \operatorname{Trp}(50 \mu \mathrm{g})$ to $1 \mathrm{~mL}$ of a $10 \mathrm{mM}$ LGO in phosphate buffer ( $\mathrm{pH} 8.0$ ) complemented with a cofactor regeneration system composed of Glucose Dehydrogenase (GDH), NADP ${ }^{+}$and glucose (Scheme 3). Monitoring of the reaction using GC/MS revealed the presence of the target (i.e., Cyrene ${ }^{\circledR}$ ) alongside a sideproduct (Figure 1). Unfortunately, mass analysis did not allow the identification of it structure.

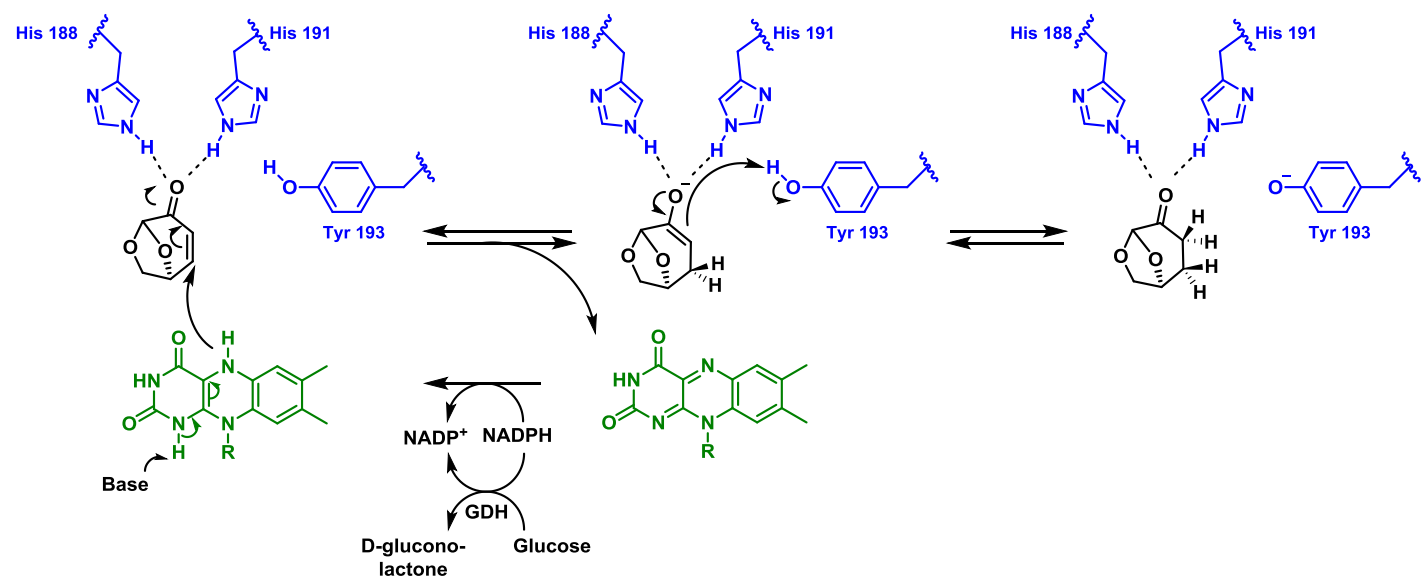

Scheme 3. Alkene reduction of Levoglucosenone into Cyrene ${ }^{\circledR}$ using OYE 2.6 (Proposed mechanism)

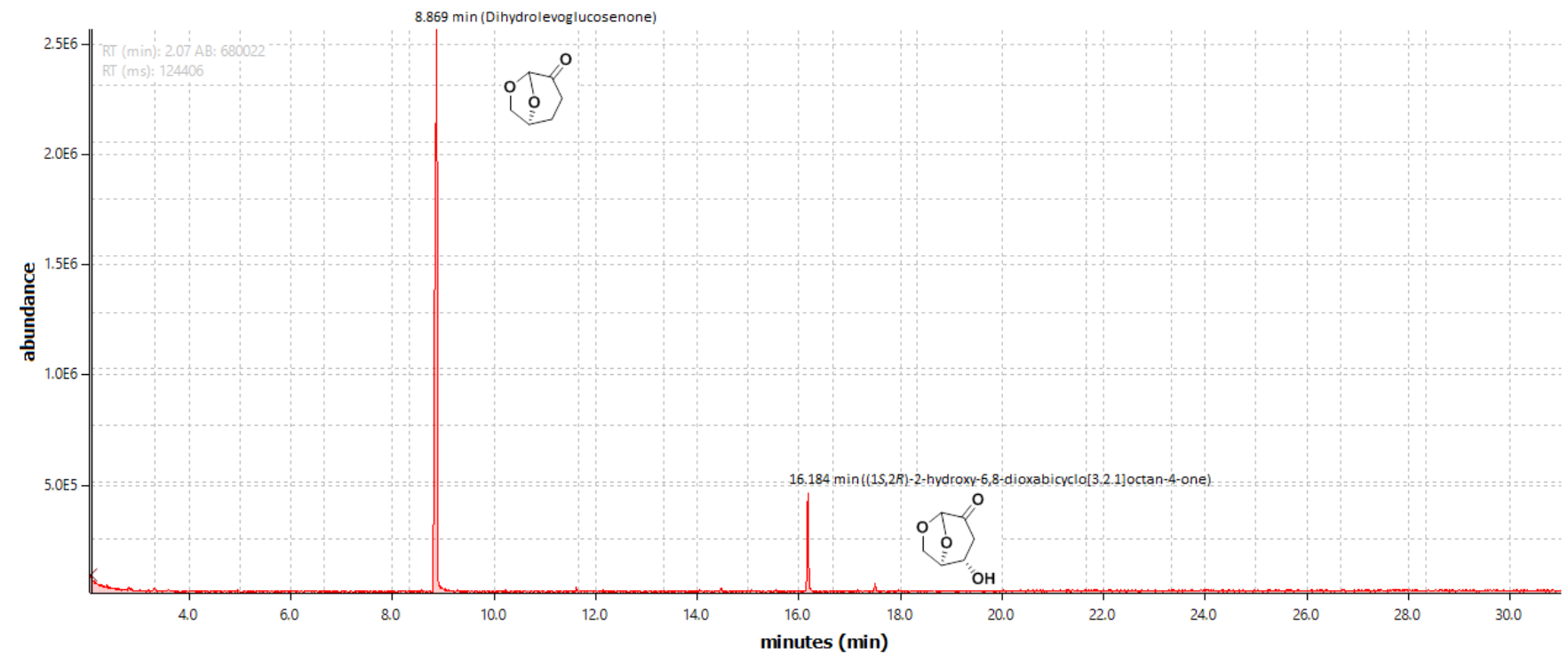

Figure 1. GC-FID analysis of non-optimized reaction conditions using OYE $26 \mathrm{Tyr}^{78} \operatorname{Trp}^{2}$

By running a negative control without OYE 2.6 $\mathrm{Tyr}^{78} \mathrm{Trp}$, the formation of the unwanted side-product was still observed. Our first assumption was that GDH reduced the ketone moiety of LGO into the corresponding alcohol. Yet, a second negative control in the absence of both OYE $2.6 \mathrm{Tyr}^{78} \mathrm{Trp}$ and GDH resulted in the same results, proving our hypothesis wrong. In view of these results, it became necessary to scale up the negative control in order to isolate a sufficient amount of the side-product to perform in-depth NMR analysis. To do so, continuous extraction of a reaction mixture composed of $10 \mathrm{mM}$ LGO in a final volume 
of $500 \mathrm{~mL}$ phosphate buffer was incubated overnight at room temperature. Multidimensional NMR analysis of the crude mixture was performed and the side-product proved to be enantiopure (1S,2R)-2-hydroxy-6,8-dioxabicyclo[3.2.1]octan-4-one (OH-LGO) (Figure 2), obtained through the phosphate-catalyzed Michael addition of water to LGO as already described in the literature (Scheme 4). . $^{30-32}$

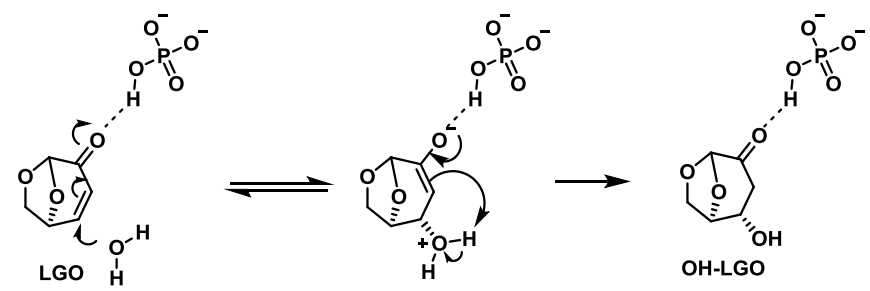

Scheme 4. Michael addition of water on LGO in phosphate buffer

To overcome this side-reaction, as the hydration of LGO is a relatively slow process, ${ }^{32}$ dropwise addition of a solution of LGO in ethanol to the reaction mixture containing OYE 2.6 $\mathrm{Tyr}^{78} \mathrm{Trp}$, NADP+, GDH and glucose in phosphate buffer (pH 8.0) was attempted. We were delighted to observe that this procedure resulted in the total conversion of LGO into Cyrene ${ }^{\circledR}$ without any trace of the side product $\mathbf{O H}$-LGO. Continuous extraction using ethyl acetate allowed us to isolate Cyrene ${ }^{\circledR}$ in quantitative yield (99\%). This extraction step using ethyl acetate is unfortunately necessary considering the working concentration and volume.

Our objective being to offer a synthetic procedure compatible for uses of Cyrene ${ }^{\circledR}$ in the food/feed, cosmetic and pharmaceutical industries, the same assay was performed using wild-type OYE 2.6 (OYE 2.6 wt.) to check whether an unmodified enzyme could be used. Here again, total conversion (99\%) of LGO into Cyrene ${ }^{\circledR}$ and absence of any OH-LGO traces were observed.

In summary, the proof-of-concept of the preparation of Cyrene ${ }^{\circledR}$ from LGO through an OYE 2.6-mediated biocatalytic process in water has been validated. However, the current procedure presents two major drawbacks to be economically or industrially relevant for multi-kilo production of Cyrene ${ }^{\circledR}$. The first one is the low concentration used. One solution to overcome it would be the continuous extraction of $C_{\text {rene }}{ }^{\circledR}$ from the reaction medium using membrane contactor. ${ }^{33,34}$ Indeed, this membrane-based technique consisting in the continuous extraction of Cyrene ${ }^{\circledR}$ while avoiding the contact of the extracting phase (i.e., organic solvent, here ethyl acetate) with the enzyme should not only improve the productivity but also preserve enzyme activity. The second drawback is the use of glucose as hydride donor. Although this is a very convenient way to regenerate NADPH on small scale for proof-of-concept, other enzymatic and non-enzymatic alternatives, such as the ones described by Wang et al. ${ }^{35}$ can be used for industrial scale synthesis.

\section{Conclusion}

In this paper, a low toxicity and greener method to access Cyrene ${ }^{\circledR}$ has been developed and optimized from Levoglucosenone (LGO) using biocatalysis. The use of an alkene reductase from Acinetobacter sp. (OYE 2.6) allows to reach total conversion of the substrate into Cyrene ${ }^{\circledR}$ while avoiding the formation of a byproduct, (1S,2R)-2-hydroxy-6,8-dioxabicyclo[3.2.1]octan-4-one (OHLGO). In an effort to develop a multi-kilo route to Cyrene ${ }^{\circledR}$ based on this biocatalytic alkene reduction, the use of industrially relevant NADPH regeneration systems and a new purification method involving membrane-contactor will be investigated and reported in due course.

\section{Acknowledgements}

This work was partially supported by the National Science Foundation (CHE-1111791). The authors are grateful to Circa Group for providing them with industrial grade Levoglucosenone, and to Région Grand Est, Conseil Départemental de la Marne and Grand Reims for financial support.

\section{Experimental Section}

General: Evaporations were conducted under reduced pressure at temperatures below $35{ }^{\circ} \mathrm{C}$ unless otherwise noted. ${ }^{1} \mathrm{H}$ NMR spectra were recorded at $300 \mathrm{MHz}$ at $25^{\circ} \mathrm{C}$ in the indicated solvent and referenced to residual protons $\left(\mathrm{CDCl}_{3}, 7.26 \mathrm{ppm} ; \mathrm{CD}_{3} \mathrm{OD}\right.$, $\left.4.87 \mathrm{ppm} ; \mathrm{D}_{2} \mathrm{O}, 4.75 \mathrm{ppm}\right) .{ }^{13} \mathrm{C}$ NMR spectra were recorded at $75 \mathrm{MHz}$ at $25^{\circ} \mathrm{C}$ in the indicated solvent and referenced to solvent $\left(\mathrm{CDCl}_{3}, 77.2 \mathrm{ppm} ; \mathrm{CD}_{3} \mathrm{OD}, 49.2 \mathrm{ppm}\right)$.

GC/MS methods: Enzymatic reactions were extracted with EtOAc and $0.01 \%$ methyl benzoate was added as an internal standard). A $1.0 \mu \mathrm{L}$ portion of the organic layer was used for GC/MS analysis (EI) equipped with a DB-17 column (0.25 mm $\times 30$ 
$\mathrm{m}, 0.25 \mu \mathrm{m}$ film thickness) using the following conditions: $60{ }^{\circ} \mathrm{C}(2 \mathrm{~min})$ to $250{ }^{\circ} \mathrm{C}(15 \mathrm{~min})$ at $10{ }^{\circ} \mathrm{C}$. $\mathrm{min}^{-1}$. These conditions allowed baseline separation of all relevant analytes in this study (Methyl-benzoate, $t_{r}=7.89 \mathrm{~min}$; LGO, $t_{r}=7.08 \mathrm{~min} ; \mathrm{HBO}, t_{r}=$ $10.91 \mathrm{~min}$; OH-LGO, $t_{r}=16.18 \mathrm{~min}$; Cyrene $^{\circledR}, t_{r}=8.86 \mathrm{~min}$ ).

Synthesis of (1R)-6,8-dioxabicyclo[3.2.1]octan-4-one (2H-LGO): 10\% Pd/C (10\% w/w, $100 \mathrm{mg}$ ) was added to a solution of LGO (1 $\mathrm{g}, 7.96 \mathrm{mmol})$ in EtOAc $(40 \mathrm{~mL}, 0.2 \mathrm{M})$ at $\mathrm{rt}$. The stirred suspension was degassed 3 times and kept under nitrogen. The suspension was then hydrogenated under a hydrogen atmosphere at room temperature until TLC showed complete consumption of the starting material. The crude mixture was filtered over a pad of Celite and the filtrate was concentrated to dryness with silica gel. The crude product was purified by silica gel chromatography (elution with 10 to $60 \%$ EtOAc in cyclohexane) to yield pure $\mathbf{2 H}$-LGO (colorless oil, $88 \mathrm{mg}, 87 \%$ ). ${ }^{1} \mathrm{H}$ and ${ }^{13} \mathrm{C}$ NMR data matched those reported by Allais et al. ${ }^{20}$

Overexpression and Purification of OYE 2.6 (wt. and $\mathrm{Tyr}^{78} \mathrm{Trp}$ ) Crude Lysate from Acinetobacter sp.: The plasmids that overexpressed OYE 2.6 (wt. and Tyr ${ }^{78} \mathrm{Trp}$ ) were used to transform E. coli BL21(DE3) cells with selection for ampicillin resistance $(100 \mu \mathrm{g} / \mathrm{mL})$ on LB plates. Single colonies of the strains were used to inoculate $12 \mathrm{~mL}$ portions of liquid LB medium containing 50 $\mu \mathrm{g} / \mathrm{mL}$ ampicillin and the culture was grown overnight at $37{ }^{\circ} \mathrm{C}$ and $250 \mathrm{rpm}$. An aliquot $(10 \mathrm{~mL})$ was diluted into $1 \mathrm{~L}$ of the same medium in a $2 \mathrm{~L}$ baffled flask. The culture was grown at $37{ }^{\circ} \mathrm{C}$ with stirring at $250 \mathrm{rpm}$ until reaching an optical density of 0.6 at $600 \mathrm{~nm}$. Overexpression of OYE 2.6 was induced by adding sterile isopropyl $\beta$-D-thiogalactopyranoside (IPTG) to a final concentration of $0.5 \mathrm{mM}$. The culture was incubated for an additional $4 \mathrm{~h}$ at $30{ }^{\circ} \mathrm{C}$, then the cells were harvested by centrifugation $\left(6000 \times \mathrm{g}\right.$ at $4{ }^{\circ} \mathrm{C}$ for $\left.15 \mathrm{~min}\right)$. The cell paste was resuspended in $6 \mathrm{~mL}$ of cold lysis buffer $(50 \mathrm{mM} \mathrm{Tris-HCl,} \mathrm{pH} 8.0)$ and disrupted by two passages through a French pressure cell at 18,000 psi. The lysate was clarified by centrifugation $(18,000 \times g$ for $20 \mathrm{~min}$ at $4{ }^{\circ} \mathrm{C}$ ). The resulting supernatant was passed through $10 \mathrm{~mL}$ of glutathione agarose (Clontech) using an FPLC system (Pharmacia) with $1 \times$ PBS buffer as the mobile phase. Once the A280 returned to a baseline reading, the desired protein was eluted by adding $10 \mathrm{~mL}$ of reduced glutathione $(10 \mathrm{mM}$, freshly prepared) in Tris- $\mathrm{HCl}(50 \mathrm{mM}, \mathrm{pH} 8.0)$, and then the appropriate fractions were concentrated to $\sim 20-40 \mathrm{mg} / \mathrm{mL}$ by ultrafiltration (Amicon Ultra-4 membrane, $10000 \mathrm{NMWL}$ ). An equal volume of glycerol was added prior to storage at $-20^{\circ} \mathrm{C}$.

Enzymatic Assay for the Alkene Reduction of LGO Using Purified OYE 2.6 Tyr ${ }^{78}$ Trp: To a solution containing $10 \mathrm{mM}$ LGO, $2.5 \mathrm{U}$ of GDH, $200 \mathrm{mM}$ glucose and $0.3 \mathrm{mM} \mathrm{NADP}^{+}$in $1 \mathrm{~mL} \mathrm{Na}{ }_{2} \mathrm{PO}_{4}$ buffer $(100 \mathrm{mM})$ was added $50 \mu \mathrm{g}$ of purified OYE $2.6 \mathrm{Tyr}^{78} \mathrm{Trp}$ and the solution was incubated at rt overnight. The reaction mixture was then centrifuged at $12,000 \mathrm{rpm} / 20^{\circ} \mathrm{C}$ for 2 minutes and the supernatant was extracted with EtOAc that also contained $0.01 \%$ methyl benzoate as an internal standard. The organic layer was analyzed by GC/MS.

Enzymatic Assay for the Alkene Reduction of LGO Using Purified OYE 2.6 wt.: To a solution containing 10 mM LGO, 2.5 U of $\mathrm{GDH}, 200 \mathrm{mM}$ glucose and $0.3 \mathrm{mM} \mathrm{NADP}^{+}$in $1 \mathrm{~mL} \mathrm{Na} \mathrm{PO}_{4}$ buffer $(100 \mathrm{mM}$ ) was added $50 \mu \mathrm{g}$ of purified OYE 2.6 wt. and the solution was incubated at $\mathrm{rt}$ overnight. The reaction mixture was then centrifuged at $12,000 \mathrm{rpm} / 20^{\circ} \mathrm{C}$ for 2 minutes and the supernatant was extracted with EtOAc that also contained $0.01 \%$ methyl benzoate as an internal standard. The organic layer was analyzed by GC/MS.

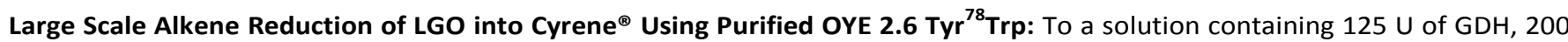
$\mathrm{mM}$ glucose, $0.3 \mathrm{mM} \mathrm{NADP}^{+}$and $50 \mu \mathrm{g}$ of purified OYE $2.6 \mathrm{Tyr}^{78} \operatorname{Trp}$ in $50 \mathrm{~mL} \mathrm{Na}{ }_{2} \mathrm{PO}_{4}$ buffer $(100 \mathrm{mM})$ was added dropwise $60 \mu \mathrm{L}$ of LGO dissolved in $1.5 \mathrm{~mL}$ EtOH over 6 hours. The reaction mixture was submitted to continuous extraction overnight using EtOAc. The organic layer was directly analyzed by GC/MS to confirm the completion of the reaction. The organic layer was evaporated in vacuo to yield pure Cyrene ${ }^{\circledR}$.

\section{Notes and references}

1. F. Shafizadeh, Y. Z. Lai and C. R. McIntyre, J. Appl. Polym. Sci., 1978, 22, 1183-1193.

2. G. R. Court, C. H. Lawrence, W. D. Raverty and A. J. Ducan, US20120111714, 2011.

3. J. Sherwood, M. de Bruyn, A. Constantinou, L. Moity, C. R. McElroy, T. J. Farmer, T. Duncan, W. Raverty, A. J. Hunt and J. H. Clark, Chem. Commun. , 2014, 50, 9650-9652.

4. J. E. Camp, ChemSusChem, 2018, 11, 3048-3055.

5. K. L. Wilson, J. Murray, C. Jamieson and A. J. B. Watson, Org. Biomol. Chem., 2018, 16, 2851-2854.

6. K. L. Wilson, J. Murray, C. Jamieson and A. J. B. Watson, Synlett, 2018, 29, 650-654.

7. L. Mistry, K. Mapesa, T. W. Bousfield and J. E. Camp, Green Chem., 2017, 19, 2123-2128.

8. H. J. Salavagione, J. Sherwood, M. De Bruyn, V. L. Budarin, G. J. Ellis, J. H. Clark and P. S. Shuttleworth, Green Chem., 2017, 19, 25502560.

9. K. L. Wilson, A. R. Kennedy, J. Murray, B. Greatex, C. Jamieson and A. J. B. Watson, Beilstein J. Org. Chem., 2016, 12, $2005-2011$.

10. J. Zhang, G. B. White, M. D. Ryan, A. J. Hunt and M. J. Katz, ACS Sustain. Chem. Eng., 2016, 4, 7186-7192.

11. A. Alhifthi, B. L. Harris, L. Goerigk, J. M. White and S. J. Williams, Org. Biomol. Chem., 2017, 15, 10105-10115. 
12. G. Bonneau, A. M. Peru, A. L. Flourat and F. Allais, Green Chem., 2018, 20, 2455-2458.

13. A. M. Peru, A. L. Flourat, C. Gunawan, W. D. Raverty, M. Jevric, B. W. Greatex and F. Allais, Molecules, 2016, 21, 98801-98810.

14. S. H. Krishna, D. J. McClelland, Q. A. Rashka, J. A. Dumesic and G. W. Huber, Green Chem., 2017, 19, 1278-1285.

15. S. Kudo, N. Goto, J. Sperry, K. Norinaga and J. Hayashi, ACS sust. Chem. Eng., 2017, 5, 1132-1140.

16. M. M. Zanardi, A. G. Suarez and A. M. Sarotti, J. Org. Chem., 2017, 82, 1873-1879.

17. K. P. Stockton and B. W. Greatex, Org. Biomol. Chem., 2016, 14, 7520-7528.

18. F. Allais, A. L. Flourat, A. M. Peru, A. R. S. Teixeira, F. Brunissen and H. E. Spinnler, WO 2015165957 A1 20151105, 2015.

19. V. K. Brel, A. V. Samet, L. D. Konyushkin, A. I. Stash, V. K. Belsky and V. V. Semenov, Mendeleev Commun., 2015, 25, 44-46.

20. A. L. Flourat, A. A. M. Peru, A. R. S. Teixeira, F. Brunissen and F. Allais, Green Chem., 2015, 17, 404-412.

21. G. L. Larson and J. L. Fry, Org. Reac., 2008, 71, 1-737.

22. S. J. Craythorne, K. Anderson, F. Lorenzini, C. McCausland, E. F. Smith, P. Licence, A. C. Marr and P. C. Marr, Chem. Eur. J, 2009, 15, 7090-7100.

23. T. Kawai, M. Isobe and S. C. Peters, Aust. J. Chem., 1995, 48, 115-131.

24. G. A. Tolstikov, M. E. Alder, I. N. Gaisina, F. A. Valeev and M. S. Miftakhov, Zh. Org. Khim., 1993, 29, 417-418.

25. M. Jaishankar, T. Tseten, N. Anbalagan, B. B. Mathew and K. N. Beeregowda, Interdiscip Toxicol., 2014, 7, 60-72.

26. https://rarediseases.org/rare-diseases/heavy-metal-poisoning/,

27. https://www.ema.europa.eu/documents/scientific-guideline/guideline-specification-limits-residues-metal-catalysts-metalreagents en.pdf,

28. A. C. Patterson-Orazem, B. Sullivan and J. D. Stewart, Bioorg. Med. Chem., 2014, 22, 5628-5632.

29. Y. A. Pompeu, B. Sullivan, A. Z. Walton and J. D. Stewart, Adv. Synth. Catal., 2012, 354, 1949-1960.

30. F. Shafizadeh, R. Furneaux, D. Pang and T. T. Stevenson, Carbohydr. Res., 1982, 100, 303-313.

31. F. Shafizadeh, R. H. Furneaux and T. T. Stevenson, Carbohydr. Res., 1979, 71, 169-191.

32. S. H. Krishna, T. W. Walker, J. A. Dumesic and G. W. Huber, ChemSusChem, 2016, 10, 129-138.

33. I. Souchon, V. Athès, F.-X. Pierre and M. Marin, Desalination, 2004, 163, 39-46.

34. G. Burgé, F. Chemarin, M. Moussa, C. Saulou-Bérion, F. Allais, H.-E. Spinnler and V. Athès, J. Chem. Technol. Biotechnol., 2016, 91, 2705-2712.

35. X. Wang, T. Saba, H. H. P. Yiu, R. F. Howe, J. A. Anderson and J. Shi, Chem, 2017, 2, 621-654. 